Meta

Journal des traducteurs

Translators' Journal

\title{
And/et analyse distributionnelle de la conjonction copulative en français et en anglais
}

\section{Geneviève Quillard et Georges Akhras}

Volume 41, numéro 3, septembre 1996

URI : https://id.erudit.org/iderudit/003895ar

DOI : https://doi.org/10.7202/003895ar

Aller au sommaire du numéro

Éditeur(s)

Les Presses de l'Université de Montréal

ISSN

0026-0452 (imprimé)

1492-1421 (numérique)

Découvrir la revue

Citer cet article

Quillard, G. \& Akhras, G. (1996). And/et analyse distributionnelle de la conjonction copulative en français et en anglais. Meta, 41(3), 459-470. https://doi.org/10.7202/003895ar
Résumé de l'article

Les auteurs dégagent des schémas indiquant les tendances et les différences à propos de la traduction de la conjonction copulative and/et; ils croient que les tendances ainsi dégagées peuvent fournir un certain nombre de points de repère aux étudiants. 


\section{AND/ET ANALYSE DISTRIBUTIONNELLE DE LA CONJONCTION COPULATIVE EN FRANÇAIS ET EN ANGLAIS}

GeneviÈve Quillard ET Georges AkHRAS

Collège royal militaire du Canada, Kingston, Canada

\section{Résumé}

Les auteurs dégagent des schémas indiquant les tendances et les différences à propos de la traduction de la conjonction copulative and/et; ils croient que les tendances ainsi dégagées peuvent fournir un certain nombre de points de repère aux étudiants.

\section{Abstract}

Using a corpus of computerized texts, the authors examine patterns and problems encountered in the translation of the coordinating conjunction And and its counterpart Et. They feel that their observations can be helpful to students.

La préférence du français pour la juxtaposition et la plus grande fréquence de «and» par rapport à son «équivalent» français ont été mentionnées à plusieurs reprises ${ }^{1}$, mais seule l'analyse informatisée de documents traduits permet de chiffrer l'écart qui sépare l'utilisation de cette conjonction copulative dans les discours anglais et français. Or, d'après les données dont nous disposons actuellement, il est considérable, comme l'illustrent les tableaux ${ }^{2}$ et les figures ci-dessous.

\begin{tabular}{|c|c|c|c|c|c|c|c|}
\hline \multicolumn{8}{|c|}{ Textes Anglais - Français } \\
\hline Nom & \multicolumn{3}{|c|}{ «AND» } & \multicolumn{3}{|c|}{$\langle E T »$} & Diff \\
\hline & Nombre & Total & $\%$ & Nombre & Total & $\%$ & $\%$ \\
\hline 1968 & 8 & 192 & 4.167 & 7 & 186 & 3.763 & 11 \\
\hline Actua & 10 & 235 & 4.255 & 8 & 228 & 3.509 & 21 \\
\hline éditeur & 8 & 219 & 3.653 & 6 & 239 & 2.510 & 46 \\
\hline Michèle & 11 & 321 & 3.427 & 10 & 329 & 3.040 & 13 \\
\hline sommaire & 8 & 285 & 2.807 & 7 & 295 & 2.373 & 18 \\
\hline armée & 117 & 2262 & 5.172 & 114 & 2797 & 4.076 & 27 \\
\hline Bagdad & 76 & 1976 & 3.846 & 36 & 1371 & 2.626 & 46 \\
\hline Égypte & 36 & 821 & 4.385 & 30 & 1052 & 2.852 & 54 \\
\hline Franco & 55 & 1805 & 3.047 & 103 & 4076 & 2.527 & 21 \\
\hline Jana & 17 & 508 & 3.346 & 15 & 573 & 2.618 & 28 \\
\hline 131 & 262 & 7516 & 3.486 & 169 & 6554 & 2.579 & 35 \\
\hline 132 & 154 & 5570 & 2.765 & 125 & 5479 & 2.281 & 21 \\
\hline 134 & 202 & 5681 & 3.556 & 166 & 5513 & 3.011 & 18 \\
\hline \multicolumn{8}{|c|}{ Moyenne } \\
\hline
\end{tabular}

Tableau 1 : Pourcentage de «and/et» des textes étudiés 


\begin{tabular}{|c|c|c|c|c|c|c|c|}
\hline \multicolumn{8}{|c|}{ Textes Français - Anglais } \\
\hline Nom & \multicolumn{3}{|c|}{ «ET» } & \multicolumn{3}{|c|}{ «AND» } & Diff \\
\hline \multirow{8}{*}{$\begin{array}{l}\text { Chantale } \\
\text { Landry } \\
\text { Denise } \\
\text { Norda } \\
\text { classic } \\
\text { Demers } \\
\text { Trialogue }\end{array}$} & Nombre & Total & $\%$ & Nombre & Total & $\%$ & $\%$ \\
\hline & 53 & 2122 & 2.498 & 63 & 1864 & 3.380 & 26 \\
\hline & 17 & 393 & 4.326 & 20 & 409 & 4.890 & 12 \\
\hline & 37 & 1958 & 1.890 & 51 & 1846 & 2.763 & 32 \\
\hline & 103 & 4076 & 2.527 & 111 & 4088 & 2.715 & 7 \\
\hline & 93 & 2807 & 3.313 & 101 & 2969 & 3.402 & 3 \\
\hline & 52 & 1251 & 4.157 & 51 & 1096 & 4.653 & 11 \\
\hline & 647 & 25928 & 2.495 & 699 & 24621 & 2.839 & 12 \\
\hline & & & & & & Moyen & 15 \\
\hline
\end{tabular}

Tableau 2: Pourcentage de «et/and» des textes étudiés
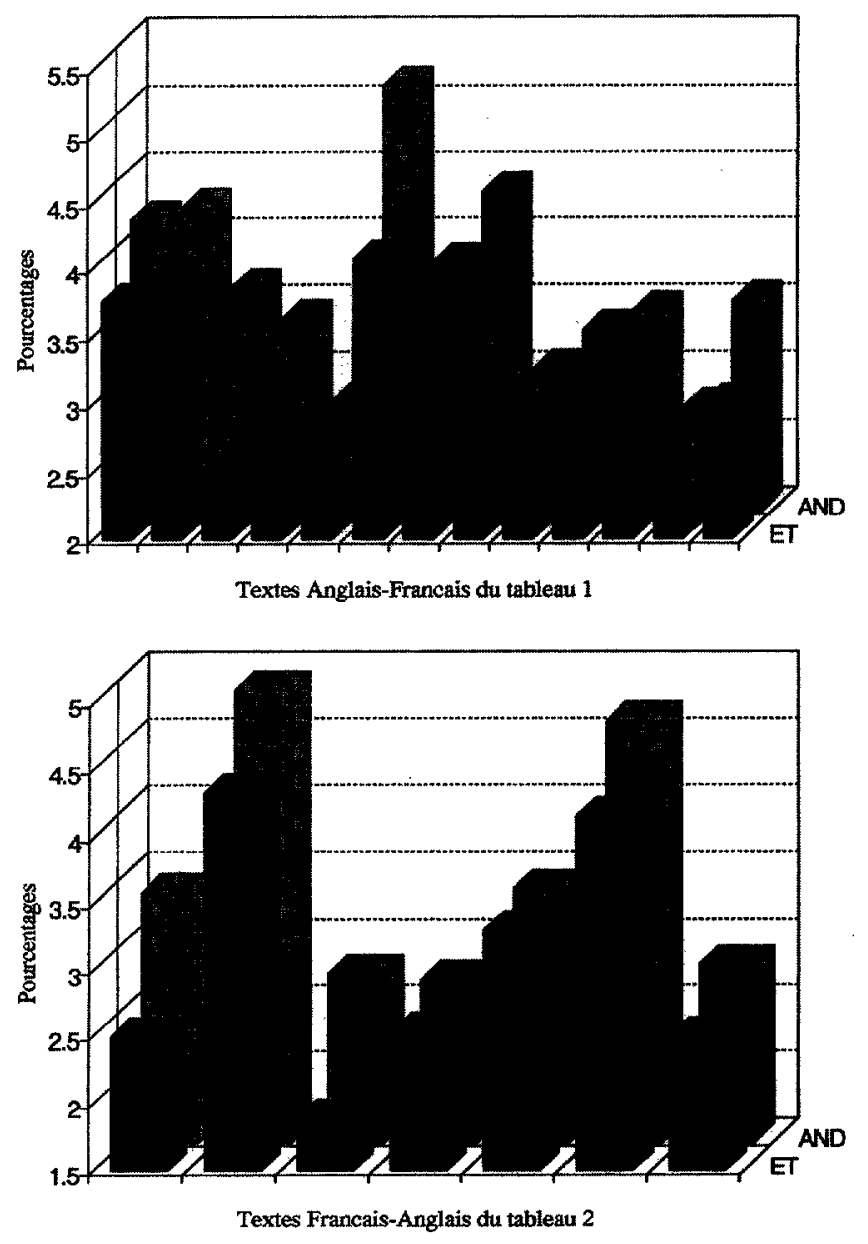
Ces variations s'expliquent en partie par la différence du système de repérage des deux langues et par le fait que l'anglais décrit la réalité au lieu de l'interpréter. Mais, pour rendre pleinement compte de ce phénomène, il faut également faire intervenir deux autres paramètres, stylistiques et culturels plutôt que linguistiques: la tolérance beaucoup plus grande de l'anglais pour la répétition ${ }^{3}$, ainsi que la plus grande complexité syntaxique des phrases françaises (dans les textes pragmatiques du moins).

Si les traducteurs chevronnés reproduisent instinctivement les caractéristiques discursives de la langue-cible, et se montrent d'ailleurs remarquablement inventifs en français (nous avons dénombré une cinquantaine de traductions de «and», allant de: par ailleurs, du reste, également, de plus, en outre, aussi, qui plus est, bref, oui, donc, sans compter, sans oublier, doublé de, accompagné de, etc., aux appositions et aux divers remaniements structuraux), tel n'est pas le cas des apprentis-traducteurs qui, eux, reproduisent avec une fidélité parfois incongrue les structures du texte-source. Sur le plan pédagogique, se pose alors la question: comment amener les étudiants à ne plus systématiquement traduire les éléments coordonnants par leur «équivalent» dans l'autre langue?

Les schémas distributionnels suivants, dégagés à partir de l'analyse de textes pragmatiques traduits du français et de l'anglais ${ }^{4}$, peuvent s'avérer utiles dans les cours de traduction comme dans les cours de rédaction avancée. Certes, ils n'ont rien de prescriptif, chaque scripteur ou traducteur ayant toujours la possibilité de faire un choix personnel et même d'aller à contre-courant, si tel est son bon plaisir, mais ils reflètent des tendances dans l'organisation collective des discours anglais et français et, à ce titre, ils peuvent fournir un certain nombre de points de repère aux étudiants.

\section{COORDINATION DE PARAGRAPHES}

Il est extrêmement rare que deux paragraphes soient coordonnés par «et» en français. Dans les traductions en français, soit la conjonction copulative est prestement éliminée, surtout si elle est suivie d'une autre articulation logique, comme dans les exemples 3 et 4 :

And when our athletes win - Canada wins. /Quand nos athlètes remportent les honneurs, c'est le Canada tout entier qui gagne! (Publicité du gouvernement du Canada, Canadian, $7 / 92$, p. 54)

And if my priority were to devise a general strategy / Si ma priorité consistait à établir une stratégie générale (Ecodecision, $9 / 91$, pp. 29, 28)

And finally, as a result of its experience/Enfin, à la suite de son expérience (Bulletin, Fédération canadienne des sciences sociales, vol. $5, \mathrm{n}^{\circ} 1,4 / 93, \mathrm{p} .2$ )

And yet one's heart must go out to someone/Néanmoins, il faut avoir de la compassion (MDN, Communiqué, 9/90, p. 1)

And speaking of outdoor events/Parlant d'activités en plein air (TVO, Signal, 8/93,

And, I believe [...] gradualism is the right path to follow/Je suis convaincu [...] que l'étapisme est la voie que doit emprunter l'administration fédérale (Langue et Société, $\mathrm{n}^{\circ} 10$, été 1983 , pp. 16, 17)

And so it soon became painfully clear/Il devient bientôt évident (L'Ontario et son peuple, ministère de l'Éducation, p. 10)

Soit elle est remplacée par une autre articulation:

And the unit has met with a lot of success so far./En fait, l'unité a déjà accumulé de nombreux succès. (Sentinelle, oct/nov 1992, p. 4) 
And, although we have been told by base civilian personnel officers/De plus, bien que des agents du personnel civil de différentes bases nous aient dit que (MDN, Communiqué, 9/90, p. 1)

And every Budget car goes through a thorough set of quality/maintenance checks / De plus, nous procédons à un entretien complet et à ún contrôle de qualité de chaque voiture Budget (publicité, Budget, Time, 3/5/93; L'Actualité, 1/6/93)

And that was the disturbing element/C'est d'ailleurs ce qui nous a semblé paradoxal (MDN, Communiqué, 3/92, pp. 2, 3)

Dans les traductions en anglais, elle est assez souvent rajoutée, surtout si le paragraphe débute par le gallicisme: c'est... que :

Sans oublier votre cerveau, qui a besoin d'eau pour donner son rendement maximal. / And don't forget your brain. It also needs water to perform at its optimum level. (publicité, Evian, Time, 14/6/93; L'Actualité, 7/93)

C'est ainsi qu'on retrouvera le professeur Humphrey à Charlottetown, cet été / And so professor Humphrey will be in Charlottetown this summer (Forces, été 1990, pp. 51, 51)

C'est justement au nom de l'équité sociale que Michel Clair sonne l'alarme aujourd'hui./And it is precisely in the name of social equity that Michel Clair is now sounding the alarm. (Forces, été 1990, pp. 56, 58)

\section{COORDINATION DE PHRASES}

Ici encore, d'une manière générale, le français évite de relier les phrases par «et», préférant la juxtaposition:

These children, from an early age, focus on what they want to be when they grow up. And when they do reach an age that allows them into the work force/Dès l'âge le plus tendre, ces jeunes rêvent du métier qu'ils feront lorsqu'ils seront grands. Arrivés à l'âge de se joindre à la population active (Bryan D. Palmer, Work and Unions in Canada, Secrétariat d'Etat du Canada, 1988, p. 7)

And, of course / Il est bien sûr évident (MDN, Communiqué, 10/91, p. 10)

C'est le docteur Juri qui a opéré Monumental Moria. Leur célébrité a ensuite grandi de concert. / It was Dr Juri who operated on Monumental Moria. And they became famous together as a result. (Le Monde, 6/9/88; Manchester Guardian, 18/9/88)

D'autres substances, d'autres gènes, d'autres phénomènes biologiques fins seront certainement caracterisés par les chercheurs/And the research community is confident of characterizing other substances, other genes and other subtle biological phenomena. (Forces, été 1990, pp. 42-46)

Pourtant, à cette époque déjà / And yet, already during this period (Jean Delisle, Au cour du trialogue canadien, Secrétariat d'État, 1984, p. 27)

A company has to be formed [...] And then the product has to be marketed/Une compagnie doit être établie [...] Le produit doit ensuite être mis en marché (Bulletin, Fédération canadienne des études humaines, 13-1)

And, says terminal-services superintendent/Comme le dit le surintendant des services de l'aérogare (En Route, 12/91, pp. 9, 11)

Ou d'autres éléments coordonnants :

There are male buyers [...] and female buyers [...] And, of course, toys / On trouve ici des acheteurs [...], des acheteuses [...] On voit aussi des jeux et des jouets, bien entendu (En Route, 12/91, pp. 29-30) 
And the short-term challenge is clear/Quant au défi que nous devons relever à brève échéance, il se présente, lui aussi, clairement à notre esprit (David Crombie, Status Report by the Secretary of State of Canada, 1988, p. 1)

The funding was adequate and it was available. And the programme has been mightily successful/Le financement était suffisant, et les fonds étaient disponibles. Ajoutons que le programme jouissait d'une grande popularité (Bulletin ACPU, $5 / 89$, vol. $36, \mathrm{n}^{\circ} 5$, p. 3 )

If true, then our lobbying, both of the public and of key policy formulators, should be entirely based on economic arguments. And certainly such arguments have worked fairly well where they have been used./Si c'est le cas, les pressions exercées auprès du public et des décideurs de politiques clés ne devraient alors être étayées que par des arguments d'ordre économique. Il n'en reste pas moins que jusqu'à présent, ce type d'argument s'est révélé assez efficace (Bulletin ACPU, 9/89, p. 5)

And, oh, it catches fire and explodes easily./Sans compter que le solvant est inflammable et explose facilement. (MDN, Communiqué, 11/90, p. 6)

Enfin, comment ne pas remarquer que Georges Pinault [...] a été nommé [...] maître de conférences associé de celte ancien ?/And it is no coincidence that [...] Georges Pinault [...] was appointed associate lecturer in Celtic (Le Monde, 18/5/90; Manchester Guardian, $24 / 6 / 90)$

\section{COORDINATION DE PROPOSITIONS}

a) Lorsque la phrase comporte trois propositions ou plus, le français a tendance soit à les juxtaposer :

Quoi encore? Aménager un Village olympique, concevoir un programme culturel, mettre sur pied tous les systèmes électroniques de communications, organiser les centres de presse et d'information du public, commercialiser la vente des billets à l'échelle mondiale./Other tasks included building an Olympic Village, organizing a cultural program, acquiring timing and measuring equipment, defining communications requirement, arranging for global communications and promoting the world-wide sale of tickets to the various Game events. (Jeux de la XXIe Olympiade, Montréal 1976, p. 4)

Soit à n'utiliser une conjonction copulative que devant la dernière. L'anglais ne manifeste pas du tout les mêmes pudeurs stylistiques:

The English by-laws were duly approved and will be printed and sent out/Le règlement intérieur anglais a été dûment approuvé; il va être imprimé et envoyé (Compte rendu de l'assemblée générale annuelle de l'ATIO, 31/10/87)

b) Pour coordonner des propositions, dont l'une au moins comporte deux syntagmes reliés par «and», l'anglais n'hésite pas à user du même terme. Le français préfère juxtaposer les propositions pour éviter la répétition:

It was then quite fashionable to sit for a portrait, and over the years he established 14 branch studios in Canada and the U.S. / À cette époque, il était de bon ton de poser pour un portrait. Il ouvrit 14 autres studios au Canada et aux Etats-Unis. (Canadian, 6/92, p. 82)

and our sincere thanks go to him and to all members of the Committee and the working groups. /; nous remercions très sincèrement Richard ainsi que tous les membres du Comité et des groupes de travail. (Compte rendu de l'assemblée générale annuelle de l'ATIO, 31/10/87)

Cette fébrilité provoque le sentiment d'une découverte et d'une urgence, elle invite à une mobilisation des ressources et du marché canadien/This feverish activity has 
engendered a sense of discovery and urgency, and has led to a mobilization of resources and of the Canadian market. (Gérard Hervouet, Le Canada et le bassin du Pacifique, Secrétariat d'État du Canada, p. 7)

Ou faire appel à d'autres connecteurs:

He commandeered both the time and the subjects of the interview, and he did so chiefly by talking very loudly. /Il a monopolisé l'entrevue et les discussions; en outre, il l'a fait d'une voix bruyante. (Bulletin, Fédération canadienne des études humaines, 13/1)

Il entretient aussi d'excellentes relations avec les associations professionnelles et les universités de même qu'il accorde beaucoup d'importance aux cours de formation et de perfectionnement. / He also maintained excellent relations with professional associations and universities, and attached much importance to employee training and development. (Jean Delisle, Au cœur du trialogue canadien, Secrétariat d'État, 1984, pp. 27, 26)

Both Pablum and kerosene were invented in Canada, and so were a great many other things / Le Pablum et le kérosène ont été inventés au Canada, de même qu'une foule d'autres choses (Yvonne Van Ruskenveld, Innovation in Canada, Secrétariat d'État, 1988, pp. 9, 10)

In short, science and technology is our future and education is the key to that future / En d'autres mots, les sciences ct la technologie sont notre avenir. L'éducation, quant à elle, est la clé de l'avenir (Bulletin ACPU, 2/91, p. 11)

Wine expert Geraldine Rubino finds bottles in everyone's price range to complement both dinner and dessert, and also offers her suggestions for a little extravagance at the evening's end./La conseillère en vins, Geraldine Rubino, a trouvé des bouteilles d'une gamme de prix qui conviennent à toutes les bourses, pour accompagner le mets principal et le dessert. Elle offre également ses suggestions de petites folies pour couronner la soirée. (Actualités RAO, printemps 1993, pp. 6,4)

It is also a good practice to be natural during an interview, and this can help you feel more at ease and demonstrate your aptitudes and your knowledge/De plus, il est opportun, au cours de l'entrevue, d'être naturel; d'ailleurs ceci peut vous permettre de vous sentir plus à l'aise et plus apte à faire valoir vos possibilités (circulaire, «Preparing for a competition», Ministry of Defence, 1990, p. 6)

I am an optimist by necessity and conviction (and I also like to have the last word) / je suis optimiste tout autant par nécessité que par conviction (d'ailleurs, $\mathrm{j}$ 'aime bien avoir le dernier mot) (David Crombie, Status Report by the Secretary of State of Canada, 1988, p. 2)

c) Si deux propositions comportant deux syntagmes ou plus sont coordonnées par «et», il y a alors de fortes chances qu'un autre connecteur soit utilisé pour relier les syntagmes ou au moins deux d'entre eux :

Christmas tree lights glittered and carollers sang outside and inside/les sapins de Noël étaient illuminés et l'on chantait des cantiques tant à l'intérieur qu'à l'extérieur (Bulletin ACPU, 2/91, p. 11)

and includes a drawing and a detailed map and an explanation/et comprend un dessin de l'oiseau ainsi qu'une carte détaillée et des explications (circulaire, Federation of Ontario Naturalists, 26/9/87)

Il faut remarquer aussi que, si «and» possède le quasi-monopole de la coordination entre deux propositions, tel n'est pas le cas de son équivalent français. Nombre d'autres éléments peuvent se substituer à lui :

Of course, the right to differ is one of our most important freedoms - and [...] we exercice it often/Naturellement, le droit de diverger d'opinion est l'une de nos plus impor- 
tantes libertés - du reste [...] nous nous en prévalons souvent (David Crombie, Satus Report by the Secretary of State, 1988, p. 1)

Here's a building project that will stretch your building abilities and you'll end up with a Christmas centerpiece/Voici un projet de construction qui requiert tous vos talents; vous aurez par la même occasion une décoration de Noël (Lego Design News, vol. $9, \mathrm{n}^{\circ} 4$, hiver 1989)

Il faut également noter la plus grande fréquence des appositions en français. Elles s'avèrent d'autant plus précieuses qu'elles permettent de faire d'une pierre deux coups: éviter l'utilisation de la conjonction copulative et celle des verbes tabou, avoir ou être:

Foncièrement cosmopolite, la civilisation Viking nous a ainsi légué un art profondément original/Viking civilization was profoundly cosmopolitan, and its highly original art presents (Atlas, 8/92, p. 90)

To make matters worse, Britain was at war with France and most of her troops were needed overseas/Enfin, pour comble d'infortune, l'Angleterre, alors en guerre avec la France, ne peut guère envoyer de troupes de renfort ( $L^{\prime}$ Ontario et son peuple, ministère de l'Éducation, p. 22)

\section{COORDINATION DE GROUPES NOMINAUX}

\section{GROUPES NOMINAUX SIMPLES:}

Le français a fortement tendance à les juxtaposer, l'anglais à les lier :

C'est affaire de conditions de vie, de structures sociales, de culture./Depending on their living conditions, social structures and culture (Forces, été 1990, pp. 27, 31)

Le climat au travail doit faciliter les communications, les échanges, l'enrichissement mutuel. / The mood of the workplace should facilitate communication, exchange and mutual enrichment. (Forces, été 1990, pp. 33,37)

Ici, la Vignole est reconvertie en restaurant, musée, lieu de dégustation pour la plus grande joie des visiteurs. / Here, for the pleasure of visitors, "la Vignole" has been converted into a restaurant, museum and wine tasting centre. (Atlas, 8/92, p. 142)

Other features are purely gizmos and gadgets /II en est d'autres, toutefois, qui sont tout au plus des curiosités, des gadgets (En Route, 10/84, pp. 54, 55)

Ces poignées d'aventuriers [...] vont se métamorphoser en prodigieux hommes d'affaires, en habiles diplomates/this small band of adventurers [...] were to proved skilled business men and crafty diplomats (Atlas, 8/92, pp. 87, 89)

Les pièces hautes et claires sont habillées de boiseries finement sculptées, de tapisseries aux paysages exotiques peints à la main, de rideaux aux tissus précieux, de mosaïques de faience/the rooms are light with lofty ceilings, finely-carved panelling, hand-painted tapestries of exotic landscapes, curtains of precious material and earthenware mosaic. (Demeures et châteaux, 1\&2/90, pp. 32, 34)

Les reliques étalées, le caractère exceptionnel du plus grand trésor de cathédrale au nord des Alpes, le précieux équipement de la cathédrale sont encore aujourd'hui un symbole de l'importance de ce pèlerinage./The shown relics, the singularity of the principal cathedral relic north of the Alps, and the precious furnishings of the cathedral are a visible sign of the pilgrimage's importance even today. (Rolf Purpar, Os Oche. Unser Aachen, Meyer \& Meyer, Aachen, 1987, pp. 23, 22) 
Lorsque les deux groupes nominaux sont relativement éloignés l'un de l'autre dans la phrase, le français évite généralement d'utiliser «et»:

The project demonstrated an expanded use of DND resources to meet national environmental goals and an increased commitment/Ce travail a nécessité un recours accru aux ressources du MDN pour atteindre les objectifs nationaux en matière d'environnement, ainsi que l'engagement (Forces canadiennes, Bulletin du personnel, 12/90, p. 3)

Comme pour la coordination de propositions, il faut noter que, même si la phrase ne comporte que deux groupes nominaux, ceux-ci ne sont pas toujours reliés par «et» (ainsi que, de même que et comme lui faisant une forte concurrence), alors qu'en anglais l'utilisation de «and» est quasi systématique:

Present you current Driver's Licence and one other piece of identification/Présentez votre permis actuel ainsi qu'une autre pièce d'identité (feuillet, It's Time to Renew Your Driver's Licence, Ontario Ministry of Transportation)

I am pleased to send you the ACLA News and a brief report/J'ai le plaisir de vous faire parvenir les Nouvelles de l'ACLA ainsi qu'un rapport succinct (lettre de la présidente de l'ACLA, 10/7/90)

It's happening in rich and poor families / Cela arrive dans les familles aisées comme dans les familles pauvres (dépliant, Wife assault: it is a crime, Ontario Women's Directorate)

You'll soon be able to use postage prepaid Special Letter envelopes and Special Occasion envelopes / Bientôt, vous aurez des enveloppes port-payé pour la «Lettre Spéciale» de même que pour les occasions spéciales (dépliant, Getting ready for the ' 90 s, Canada Post Corporation, 1990)

La même remarque s'applique lorsqu'il y a plus de deux groupes nominaux:

Then we will start the change to your bill, Outlet and other bill inserts / Nous modifierons ensuite la présentation des factures, du bulletin «Échanges» ainsi que des différents prospectus d'information (Ontario Hydro, Outlet, Seasonal Customer Issue, Fall, 1990)

\section{GROUPES NOMINAUX COMPOSÉS:}

Lorsque les syntagmes nominaux coordonnés comprennent un ou plusieurs éléments coordonnants, le français évite de les relier par «et». Les formes privilégiées sont alors la juxtaposition:

Les vastes dimensions de leur territoire, le faible peuplement, les productions minières et agricoles / their vastnest, their small populations, and similar mining and farming industries (Gérard Hervouet, Le Canada et le bassin du Pacifique, Secrétariat d'État du Canada, 1988 , pp. 29, 27)

L'amélioration de la qualité de la vie, de la qualité de la nutrition, la multiplication des efforts de recherche et des gestes préventifs/improvements in the quality of life and nutrition and the step-up in research efforts and preventive measures (Forces, été 1990, pp. 19-21)

Celui-ci comportait trois thèmes: Critères d'admission et contenu des programmes de formation, Intégration et adaptation au marché du travail, Initiatives : formation et productivité./The final programme included three themes: Admission Requirements and Training Programme Content; Entering and Adapting to the Job Market; and Training and Productivity Initiatives. (InformATIO, vol. 22, $\mathrm{n}^{\circ} 3,6 / 93$, pp. 2, 4) 
Ou : ainsi que, comme, de même que :

Our General Safety Program and the dedicated professionals responsible for the formulation and implementation of that program/le programme de sécurité ainsi que le personnel affecté à la rédaction et à la mise en vigueur du programme (National Defence, General Safety Digest, $\mathrm{n}^{\circ} 4,1989 / 90, \mathrm{p} .1$ )

These include the 1970 and 1975 Christmas stamps, the 1979 International Year of the Child stamp and the 1983 issue for the 75th anniversary of Canadian Scouting./les vignettes de Noël émises en 1970 et en 1975, celle de l'Année internationale de l'enfant, en 1979 , de même que le timbre de 1983 soulignant le $75^{\mathrm{e}}$ anniversaire du mouvement scout au Canada. (brochure, Société canadienne des postes, Fenêtres de découverte, 1993, p. 7)

Entries are made with the help of translators, client departments and cooperating organizations in Canada and abroad/se font avec la collaboration des traducteurs euxmêmes, des ministères clients ainsi que d'organismes coopérants, du pays comme de l'étranger (brochure, Bureau de traduction, Secrétariat d'État du Canada, p. 3)

It was reviewed by the Academic Freedon and Tenure Committe and by the Executive./Le Comité de la liberté universitaire et de la permanence ainsi que le Comité de direction l'ont examiné. (Bulletin ACPU, 6/92, p. 1)

Mais elles ne sont pas les seules:

This [...] vocabulary contains approximatively 1,200 entries and 300 definitions and observations / Ce vocabulaire [...] comprend environ 1200 entrées assorties de 300 définitions et observations (dépliant, Pensions Vocabulary, Secrétariat d'État du Canada)

[They] must be linked with our human and economic values and our responsibility to future generations./[Ils] doivent être appliqués en harmonie avec nos valeurs humaines et économiques, dans le contexte de notre responsabilité envers les générations à venir. (MDN, Communiqué, 5/92, pp. 2,3)

\section{PHRASES COMPORTANT TROIS «AND» OU PLUS}

Comment le français pourrait-il se montrer aussi cavalier? Dans ce cas, les traductions témoignent alors d'une merveilleuse créativité, mais elles ont généralement en commun la présence d'une proposition relative :

This publication is primarily a working tool for translators and communicators and provides access to terms and expressions not commonly found in other agricultural dictionaries. /L'ouvrage est essentiellement un outil de travail où traducteurs et communicateurs pourront trouver des termes ou des expressions difficilement accessibles dans les dictionnaires agricoles courants. (dépliant, Vocabulary of Agriculture, 1991)

The Native people had a thorough knowledge of these water routes, and they were generous in sharing what they knew with the explorers and with the fur traders and missionaries that followed/Ces cours d'eau n'ont aucun secret pour les autochtones qui partagent volontiers leur savoir avec les explorateurs puis les trafiquants de fourrure et les missionnaires qui les suivent ( $L$ 'Ontario et son peuple, ministère de l'Éducation, p. 7)

The 1990 Convention and the preparatory workshops for the CTIC examination were applauded by members and deemed informative and educational development activities / Le congrès de 1990, ainsi que les ateliers préparatoires en regard de l'examen du CITC, ont été applaudis par les membres, qui ont jugé ces activités instructives et propices au perfectionnement professionnel (circulaire de l'ATIO, fin 1990) 


\section{ARTICULATIONS LOGIQUES DIFFÉRENTES}

Si l'anglais affectionne les rapports chronologiques, le français leur préfère les rapports logiques. Il faut donc amener les étudiants à effectuer une analyse sémantique des textes ou des phrases qu'ils ont à traduire, afin qu'ils choisissent le connecteur logique le mieux adapté au contexte:

a) conséquence: C'est, d'après les données dont nous disposons, le rapport le plus fréquent. Mais seule une étude portant sur un plus grand nombre de documents permettrait de confirmer cette observation.

By October 1763 , however, many Native nations had ceased to actively support the rising and the full force of the rebellion had passed/Cependant, en octobre 1763, plusieurs nations indiennes cessent de soutenir activement le soulèvement, qui perd donc de son importance (L'Ontario et son peuple, ministère de l'Éducation, p. 10)

Recycling is one of the best tools we have to alleviate the waste management problem, and federal government employees have been recycling paper since 1976./Le recyclage est l'un de nos meilleurs outils pour résoudre le problème de la gestion des déchets; c'est pour cela que les fonctionnaires fédéraux recyclent le papier de bureau depuis 1976. (Forces canadiennes, Personnel Newsletter, 12/90, p. 15)

We will be visiting your region in the fall or winter of 1993-1994 and we would appreciate hearing from you/Nous nous rendrons dans votre région l'automne ou l'hiver prochain, aussi nous souhaitons [sic] que vous communiquiez avec nous (circulaire, Commission de la fonction publique du Canada, 16/7/93, p. 2)

This Committee had spent over a year conducting a study on a science and technology strategy for Canada, and it did not want prorogation/Pendant plus d'un an, le comité a mené une étude sur une stratégie scientifique et technique pour le Canada. Il ne voulait donc pas qu'une prorogation (Bulletin ACPU, 2/91, p. 11)

The Committee acknowledged that the Archives are most inadequately housed, and that a solution must be found urgently/Le comite de la Chambre reconnait que les locaux des Archives nationales sont dans un tel état de délabrement qu'il faut absolument remédier à la situation (Bulletin, Fédération canadienne des études humaines, printemps 1988, vol. 11, $\left.\mathrm{n}^{\circ} 1, \mathrm{p} .2\right)$

We have received yet another budget cut this year, and individual contributions have a heightened importance to our program planners./Nous avons connu d'autres coupures budgétaires cette année. Les contributions individuelles revètent donc une plus grande importance pour nos planificateurs d'émissions. (TVO, Signal, 6/93, p. 3)

b) finalité :

You're trying to get rid of some of the crap and focus on things that are really important./Ils essaient de ne pas s'occuper des absurdités pour ne s'intéresser qu'aux éléments vraiment importants. (En Route, $11 / 90$, pp. 50,49)

Je vais immédiatement téléphoner à Klow pour faire arrêter le professcur Alambique. / I will telegraph at once to Klow and have Professor Alembick arrested. (Hergé, Le sceptre d'Ottokar / King Ottokar's sceptre, Casterman, 1947/Magnet edition, 1979, p. 26)

c) causalité :

Different pods "speak" in distinctive, regional dialects and researchers have recognized certain individuals solely from voice patterns/Puisque les troupes «parlent» divers dialectes régionaux, les chercheurs peuvent reconnaître certains individus d'après leur «langage» (Canadian, 5/90, p. 16) 


\section{d) opposition :}

Riourik s'empara de Novgorod, tandis que son successeur Oleg se rend maître de Kiev/Riourik took Novgorod [...] and his successor, Oleg, became master of Kiev (Atlas, $8 / 92$, p. 90 )

Yet 33 out of 37 Norstar sets took the heat and came through it in working order. / Pourtant, même s'ils ont eu très chaud, 33 combinés Norstar sur 37 fonctionnent toujours. (publicité de Northern Telecom, Time, 30/11/92; L'Actualité, 1/9/92)

Il faut également noter que le français a tendance à préférer la subordination à la coordination:

Many people buy the cheaper seats [à l'opéra, au theâtre, etc.] and this has an impact on the revenues of these organizations. / Bien des gens achètent des places moins chères, ce qui se répercute sur le total des recettes des organismes. (Bulletin ACPU, 11/92, pp. 13, 19)

The form will provide more details on the calculations involved, and will help you/La formule fournira de plus amples détails sur les calculs à effectuer, lesquels vous aideront (livret, GST, Revenu Canada, 1990, p. 13)

Winter/Summer sessions begin in February, and coincide/Les cours de la session hiver / été commencent en février, ce qui coïncide (livret, Glendon, York University, 19901991, p. 3)

The package is known as the Primary Reserve Benefit Program and will be phased in/Il s'agit du Programme d'avantages sociaux pour la Première réserve qui sera mis en cuvre graduellement (Forces canadiennes, Personnel Newsletter, 10/90, pp. 3, 2)

The statements showed a much healthier financial position and were duly adopted./Les états financiers, qui reflétaient une situation financière assainie, ont été dûment adoptés. (Compte rendu de l'assemblée générale annuelle de l'ATIO, 31/10/87)

All you need to do is put a mortgage on your house and fund it with the money in your RRSP/La seule chose à faire, c'est d'hypothéquer votre maison en finançant l'opération grâce à l'argent du REÉR (En Route, 10/84, p. 33)

I peered into the main shaft, and the air rose to meet me, clammy and oppressive /Quand je me suis penché sur le puits principal, une bouffée d'air froid et humide m'a frappé au visage avec une odeur de renfermé (En Route, 10/89, pp. 78, 77)

The Bureau has developed and is refining a system/Le Bureau a mis au point un système d'expertise qu'il raffine sans cesse (livret, Bureau de traduction, Secrétariat d'État du Canada, p. 4)

\section{CONCLUSION}

Comme nous l'avons dit dans l'introduction, traducteurs ou scripteurs disposent toujours d'une liberté d'action ou d'une marge de manœuvre qui peut les amener soit à «dévier» des sentiers battus, c'est-à-dire à choisir une forme qu'évitent d'utiliser les membres de la collectivité linguistique à laquelle ils appartiennent, soit à faire preuve de créativité et d'originalité sur le plan syntaxique comme sur le plan lexical. C'est la raison pour laquelle les schémas que nous avons dégagés sont loin d'être rigides: ils ne font qu'indiquer des tendances. Nous pensons toutefois qu'ils pourraient servir de guides et sont susceptibles d'amener les étudiants à traduire ou à produire des textes qui soient exempts de toute interférence, si minime soit-elle.

Les différences que nous avons relevées à propos de la conjonction copulative and/et se manifestent au niveau d'autres connecteurs, qui sont nettement plus nombreux 
et plus variés en français, et qui mériteraient d'être étudiés de près pour tenter de prévoir leurs occurrences, notamment au niveau de la liaison entre les paragraphes. Ici encore, il devrait être possible de repérer des tendances, des préférences, voire des réticences discursives, ce qui pourrait avoir des applications pratiques immédiates pour l'enseignement.

\section{REMERCIEMENTS}

Nous tenons à remercier tous ceux qui nous ont envoyé des documents sur disquette: M. Jean Delisle, de l'Université d'Ottawa, le service de traduction du Royal Museum of Ontario, la Fédération canadienne des études humaines, ainsi que le ministère de la Défense nationale.

\section{Notes}

1. Notamment par Françoise Grellet (1991), p. 177, Jacqueline Guillemin-Flesher, p. 61, et par Vinay et Darbelnet, p. 229.

2. Les tableaux fournissent, pour chaque texte analysé, le nombre de and et de et, le nombre de mots et le pourcentage de la conjonction copulative. La dernière colonne donne la différence du pourcentage de and et et.

3. Voir par exemple M. Ballard, p. 232, F. Grellet (1985), p. 186, G. Quillard (à paraître).

4. La présentation des exemples suit l'ordre texte-source/texte cible.

\section{RÉFÉRENCES}

BALLARD, Michel (1987) : La traduction : de l'anglais vers le français, Paris, Nathan.

GRELLET, Françoise (1985) : "The word against the word". Initiation à la version anglaise, Paris, Hachette.

GRELLET, Françoise (1991) : Apprendre à traduire, Presses Universitaires de Nancy.

GUILLEMIN-FLESHER, Jacqueline (1986): «Le linguiste devant la traduction», Traduire, Presses Universitaires de Lille, 7.

QUILLARD, Geneviève (à paraître) : «Étude de certaines différences dans les écrits anglais et français».

VINAY, Jean-Paul et Jean DARBELNET (1958): Stylistique comparée du français et de l'anglais, Montréal, Beauchemin. 